\title{
Plasticity of Soybean Stomatal Responses to Arsenic and Cadmium at the Whole Plant Level
}

\section{Terézia Gálusová1, Beáta Piršelová ${ }^{1}$, Lubomír Rybanský, Yuliya Krasylenko ${ }^{3}$, Patrik Mészáros ${ }^{1}$, Alžbeta Blehová ${ }^{4}$, Monika Bardáčová ${ }^{*}$, Jana Moravčíková 6 , Ildikó Matušíková ${ }^{5}$}

\begin{abstract}
${ }^{1}$ Department of Botany and Genetics, The Constantine Philosopher University, Faculty of Natural Sciences, Nitra, Slovak Republic

${ }^{2}$ Department of Mathematics, Constantine the Philosopher University, Faculty of Natural Sciences, Slovak Republic ${ }^{3}$ Institute of Food Biotechnology and Genomics, NAS of Ukraine, Kyiv, Ukraine

${ }^{4}$ Department of Plant Physiology, Faculty of Natural Sciences, Comenius University, Bratislava, Slovak Republic

${ }^{5}$ Department of Ecochemistry and Radioecology, Faculty of Natural Sciences, University of SS. Cyril and Methodius in Trnava, Trnava, Slovak Republic

${ }^{6}$ Department of Biotechnology, Faculty of Natural Sciences, University of SS. Cyril and Methodius in Trnava, Trnava, Slovak Republic
\end{abstract}

Received: 3 November 2019

Accepted: 11 January 2020

\begin{abstract}
Heavy metals perturbate water balance in plants and hence impact stomatal aperture. After longer exposure, stomatal development also is affected, and stomatal density and size can change. Two soybean (Glycine max) varieties were experimentally selected for contrasting tolerance to arsenic and cadmium. For these cultivars, natural variability in leaf epidermal cell parameters was detected. Pot plants at first assimilating leaf stage were exposed for 10 days to $5 \mathrm{mg} \mathrm{kg}^{-1}$ soil As $\mathrm{As}^{3+}$ and $50 \mathrm{mg} \mathrm{kg}^{-1}$ soil $\mathrm{Cd}^{2+}$ (respectively). Metals accumulated primarily in roots and exerted relatively low impact on biomass. Despite this, we observed diverse adjustments of stomata and pavement cells. In cv. Bólyi 44 the stomatal size decreased upon stress treatment, possibly to avoid further water loss. In contrast, the other cultivar Cordoba uses larger stomata that might be advantageous in gaining further resources. The observed responses varied depending on leaf type. In addition, dorsoventral stomatal responses in width, yet undescribed under metal stress, were observed. Our data show that leaf epidermal cell adjustments are flexible components of plant defense even at low metal doses, and possibly help to compromise the structural and functional needs of plant (tissue) under metal stress.
\end{abstract}

Keywords: dorsoventral, leaf epidermis, metal, plant defense

*e-mail: bardacova.monika@gmail.com 


\section{Introduction}

Heavy metal elements like cadmium (Cd) and metalloid arsenic (As) (for simplicity we mention them both as metal henceforth) are non-essential for plants, while both can seriously damage the plants even at low concentrations and affect growth and development $[1,2]$. The mean value for As content in soils of Slovakia is $7.2 \mathrm{mg} \mathrm{kg}^{-1}$ of soil [3], and for $\mathrm{Cd} 1.24 \mathrm{mg} \mathrm{kg}^{-1}$ [4]. In some other European countries (e.g., Ireland, England, Germany and southern France) the soil pollution rate is even higher [5].

Regardless of the source (air or soil), metals enter the plants mainly through membrane channels [6]. The uptake of $\mathrm{Cd}^{2+}$ from soil occurs mainly via $\mathrm{Ca}^{2+}$, $\mathrm{Fe}^{2+}, \mathrm{Mn}^{2+}$, and $\mathrm{Zn}^{2+}$ transporters [7], and arsenic can be transported in most plants either as $\mathrm{As}^{5+}$ through the high-affinity $\mathrm{Pi}$ transport system or $\mathrm{As}^{3+}$ by aquaporinlike water membrane channels $[8,9]$. The metals (especially at higher doses) trigger the generation of molecules with active oxygen (directly or indirectly) that damage the membranes and lead to cell death when the antioxidative capacity of the cells was overcome $[6$, 10]. Inhibition of enzymes interferes in the processes of photosynthesis, metabolism and growth [11]. Another consequence of metal toxicity is a perturbation of the plant-water relationship, discussed in detail in the review of Rucinńska-Sobkowiak [12]. Already, relatively low $\mathrm{Cd}$ doses $\left(1-5 \mu \mathrm{mol} \mathrm{L}^{-1}\right.$ up to $\left.72 \mathrm{hr}\right)$ can lower osmotic potential, increase turgor and actuate stomata to open. At moderate doses $\left(5-50 \mu \mathrm{mol} \mathrm{L}^{-1}\right.$ for 3 weeks) the root tip cells degenerate, therefore water uptake and transport are impaired and stomata close; at high concentrations (above $50 \mu \mathrm{mol} \mathrm{L}^{-1}$ for more than 3 weeks) the turgor drops, metabolism breaks down and stomatal control is lost [13]. It has been demonstrated that after entering cytosol, $\mathrm{Cd}$ ions perturbate the intracellular calcium level, interfere with calcium signalling and affect (osmo) regulation of guard cells [14] by initiating callose accumulation [15]. Closure of stomata is one of the common, relatively fast plant responses to metal presence, and its mechanism is well studied [13]. However, data on alterations of stomatal size and density under metal-stress are scarce. In Arabidopsis thaliana, stomata differentiate during organ development from protodermal cells through a series of cell division and fate acquisition events. This process ends up in formation of pavement cells or undergoes asymmetric division to initiate stomatal lineages [16]. The process is under genetic control, while patterning in the leaf epidermis is species-dependent and influenced by internal anatomy [17]. Under environmental change, the corresponding signal(s) have to be sensed by a mature organ first and subsequently they are transferred to the developing primordia to initiate a developmental stomatal response [16]. Signals invoked by metals can include various reactive oxygen molecules and/or the disrupted homeostasis of essential elements, plant hormones and growth regulators [10]. There are only a few factors known as having an effect on stomatal development (in contrast to many that affect the stomatal movement). These include increased concentration of atmospheric $\mathrm{CO}_{2}$, light intensity, UV$\mathrm{B}$, drought, ozone or shade [18]. In addition, heavy metals have been reported to raise the abundancy of small-sized stomata to maximize the rate of carbon gain while minimizing water loss $[12,18,19]$. How and where the corresponding signals are perceived for such long-distance signaling in stomatal development remains unclear.

Heterogeneity has been observed for different stomatal characters, including size, density or behaviour within as well as between leaves, between plants and species [20]. The link (if any) between the stomatal responses to stresses on mature leaves and physiological and/or developmental pattern of stomata in developing leaves is obscure, and available data are contradictory [21]. A growing amount of molecular evidence indicates that the responses to environmental cues within a single plant exert a non-linear pattern and can depend on developmental stage and/or leaf position [22, 23]. Similarly, differentiation and responses of stomata are subject to different controls on upper and lower leaf surfaces, probably by ethylene [21]. While it is difficult to draw general conclusions on how different stresses impact the development of stomata and how these control the water loss $/ \mathrm{CO}_{2}$ uptake balance under altered conditions, the spatio-temporal variability in stomatal behaviour likely may provide plants with some functional advantage or disadvantage (especially of crops) [20].

In this work we studied the effects of ecologically relevant heavy metal doses on leaf epidermis of two soybean (Glycine max) varieties. As responses of leaf epidermis are metal specific [19], we applied As and $\mathrm{Cd}$ (respectively) as examples of commonly considered and highly toxic anthropogenic pollutants. These two elements can bind different types of ligands $\left(\mathrm{As}^{3+}\right.$ reacts with oxygen-containing ligands and $\mathrm{Cd}^{2+}$ with $\mathrm{S}$ - and $\mathrm{N}$-containing ligands) [22]; consequently, different impacts and plant defence strategies are expected [23]. The aim of the work was to i) study the plasticity of responses of leaf epidermal cells in soybean plants under metal stress conditions; ii) reveal the possible interacting effects of different factors such as leaf type/ position, leaf side and cultivar on stomatal features; iii) compare and conclude on possible specificity of epidermal cell responses to a certain type of metal; and iv) compare the ongoing defence strategies in two soybean cultivars in the context of metal tolerance and accumulation. 


\section{Experimental Procedures}

\author{
Soybean Seeds and Selection of Cultivars \\ with Contrasting Metal Tolerance
}

Seeds of 9 soybean (Glycine max L.) cultivars were used: Borostyán, Bóbita, Bólyi 44, Bristol, Crusader (provided by the Bóly Agricultural Production and Trade Ltd., Hungary); Cordoba, Kent (SAATBAU LINZ Slovakia Ltd., Slovakia) and Ustya and Vorskla (Institute of Agriculture of Ukrainian Agrarian Academy of Science, Ukraine). The seeds were surfacesterilized with $0.5 \%(\mathrm{w} / \mathrm{v})$ sodium hypochlorite for $10 \mathrm{~min}$, then rinsed three times in distilled water. Germination was performed in Petri dishes lined with two layers of water-moistened filter paper (Whatman No. 1) in the dark at $25^{\circ} \mathrm{C}$, until the radicle reached 3-8 $\mathrm{mm}$ in length. Uniformly germinated seeds were collected and transferred to fresh filter paper moistened with distilled water (control), $5 \mathrm{mg} \mathrm{L}^{-1} \mathrm{Cd}^{2+}$ or $5 \mathrm{mg} \mathrm{L}^{-1} \mathrm{As}^{3+}$. Metal solutions were prepared from $\mathrm{Cd}\left(\mathrm{NO}_{3}\right)_{2} \cdot 4 \mathrm{H}_{2} \mathrm{O}$ (Centralchem) and $\mathrm{As}_{2} \mathrm{O}_{3}$ (Merck). Fresh- (FW) and dry weights (DW) of the roots of 10-15 seedlings per cultivar and replicate were measured after $48 \mathrm{~h}$ of exposure; relative dry biomass of metal-treated roots with respect to controls was expressed as Tolerance index (TI) in \%. Two cultivars with contrasting sensitivity to both metals were further analyzed in pot experiments.

\section{Plant Growth Condition and Exposure to Metals in Pot Experiments}

Soybean (Glycine max) seeds of cv. Bólyi 44 and cv. Cordoba were surface-sterilized in $0.05 \%(\mathrm{v} / \mathrm{v})$ sodium hypochlorite solution (SAVO) and germinated in Petri dish $(\varnothing 12 \mathrm{~cm})$ in darkness at $25^{\circ} \mathrm{C}$ for 3 days. When the roots reached a length of 5-8 $\mathrm{mm}$, they were transferred to plastic pots $(\varnothing 25 \mathrm{~cm}$, volume $1500 \mathrm{~mL}, 15$ seeds) into a mixture of peat soil BORA ( $\mathrm{pH} 5$ to 7 , humidity $65 \%$ ) and perlite (in ratio $4: 1$ ). They were flooded with distilled water, the amount of which corresponded to the maximum sorption capacity of the soil $(\sim 700 \mathrm{~mL})$. A dose of $\mathrm{Cd}\left(50 \mathrm{mg} \mathrm{kg}^{-1}\right.$ soil $\left.\mathrm{Cd}^{2+}\right)$ in the form of $\mathrm{Cd}\left(\mathrm{NO}_{3}\right)_{2} \cdot 4 \mathrm{H}_{2} \mathrm{O}$ solution, As $\left(5 \mathrm{mg} \mathrm{kg} \mathrm{kg}^{-1}\right.$ soil $\mathrm{As}^{3+}$ ) in the form of $\mathrm{As}_{2} \mathrm{O}_{3}$ solution and distilled water as control were applied to soil in the plant stage of the first assimilation leaves (the $12^{\text {th }}$ day of experiment), respectively. Pot experiments were conducted in a growth chamber with a controlled climate at $80 \%$ relative humidity, $12 \mathrm{~h}$ light photoperiod, light intensity of $550 \mu \mathrm{mol}$ photons $\mathrm{m}^{-2} \mathrm{~s}^{-1}$ at $23^{\circ} \mathrm{C}$ with a weekly supply of sterile distilled water. The leaves of plants at growth stage V2 [24] were assigned as follows: first assimilative leaf - unifoliate (UL), the second assimilative leaf - trifoliate (TL) (basipetal direction). After 10 days of plant growth in control and contaminated soil, the dry weight (DW) and length of shoots and roots was determined for each plant using a digital analysis balance (Explorer Pro EP 114 CM) and a ruler.

\section{Measurement of the Parameters of Stomata}

The number of stomatal and pavement cells (PC) was determined on the adaxial (top) and abaxial (lower) leaf surface by applying the fingernail polish method. Specimens were observed under a light microscope (Zeiss Axioplan 2) and documented with a Sony DXC-S 500 camera. Stomatal and pavement cell densities (SD and PD, respectively) were calculated as their numbers per area unit (cell number $\mathrm{mm}^{-2}$ ) in 24 fields of view $(870 \times 650 \mu \mathrm{m})$ of each variant of the experiment. Length and width of stomata were measured using the AxioVision AC program in different fields of view. Stomatal index (SI) was calculated as a percentage of epidermal cells that were stomata. Each experiment was performed at least in triplicate. The scored leaf areas lacked trichomes and socket cells.

\section{Measurements of Metal Content in Plants}

Dried plant material (0.5 g of entire shoot/ root) was digested in a mixture of $5 \mathrm{~mL}$ water, $5 \mathrm{~mL}$ of concentrated $\mathrm{HNO}_{3}$ p.a. (Merck, Darmstadt, Germany) and $1.5 \mathrm{~mL}$ of $\mathrm{H}_{2} \mathrm{O}_{2}$ p.a. (Slavus, Bratislava, Slovakia) using a microwave oven (Anton Paar GmbH - Multiwave 3000, Praha, Czech Republic). Decomposition temperature was $140^{\circ} \mathrm{C}$, ramp time $15 \mathrm{~min}$ and hold time $13 \mathrm{~min}$. After digestion the solution was diluted to $25 \mathrm{~mL}$ with deionized water and filtered through an acid-resistant cellulose filter (Whatman No. 42).

The elements $\left(\mathrm{As}^{3+}\right.$ and $\mathrm{Cd}^{2+}$ ) were determined by electrothermal atomic absorption spectroscopy (AAS Perkin Elmer 1100B, Norwalk, Connecticut, USA) equipped with deuterium background correction and HGA 700 graphite furnace with automated sampler AS-70. As content was measured at wavelength $189 \mathrm{~nm}$, slit $1.0 \mathrm{~nm}$, and lamp current EDL 8W. Working conditions for Cd were: wavelength $228.8 \mathrm{~nm}$; slit $0.5 \mathrm{~nm}$ and lamp current EDL 4.5W. Standard stock solutions of $1000 \mathrm{mg} \mathrm{L}^{-1}$ of $\mathrm{As}^{3+} / \mathrm{Cd}^{2+}$ (Merck, Darmstadt, Germany) were used for calibration. The accuracy of the analytical results for $\mathrm{As}^{3+} / \mathrm{Cd}^{2+}$ content in plant samples was checked by the analysis of the certified reference material BCR No. 60 (trace elements in an aquatic plant). Metal transfer factor was calculated as the ratio of metal amount in shoots to roots.

\section{Histochemical Detection of Lignin}

Since lignin deposition in cell walls is an important hallmark of the activation of plant adaptive response to phytotoxic metals [25], we observed lignification in experimental tissue to confirm metal stress. Soybean seedlings were thoroughly rinsed in the distilled water. Roots of similar size as well as leaf 
stems were dissected and fixed for $24 \mathrm{~h}$ in Navashin's fixative containing $15 \mathrm{~mL}$ of $1 \% \quad(\mathrm{v} / \mathrm{v})$ chromic acid, $1 \mathrm{~mL}$ of glacial acetic acid and $4 \mathrm{~mL}$ of $38 \%$ (v/v) formaldehyde solution with further paraplast embedding. Rotary microtome (MicroTec Cut 4055) was used for the precise cutting of $7 \mu \mathrm{m}$-thick sections that undergo "dry" mounting in glycerol-albumen solution (Serva, Germany) and dried overnight at $37^{\circ} \mathrm{C}$ (Slide Warmer SW 85). Samples were put into xylene substitute AppiClear (AppliChem GMBH, Germany) (xylene 1, 2 and 3 for extra cleaning) for 3-7 min to remove paraplast with a further $3 \mathrm{~min}$ exposure to ethanol series for dehydration.

The phloroglucinol-HCl (Wiesner) reaction was used for the lignin detection as described by [26]. After the staining cross-sections were rinsed, dehydrated in ethanol series, and mounted on slides with waterglycerol (1:1), glycerol and/or xylene-alkylacrylate Entellan medium (Merck, Germany) for observation under transparent light of Axioplan 2 epifluorescence microscope (Carl Zeiss, Germany) (H/DICII, objectives Plan-Neofluar 5,10 and 20X). Representative images were obtained by a SONY DXC-S500 digital camera. Adobe Photoshop CS was used for data processing. For each metal, cultivar and tissue type at least 10 sections were characterized in a minimum of three independent replicates.

\section{Statistical Analyses}

Each experiment was performed in three replicates. The data are expressed as the mean \pm standard error of mean (SEM). For analyses of stress responses, multifactorial analyses of variance (ANOVA) were performed with planned comparisons of the means. A $P$-value below 0.05 was considered to be statistically significant. The relationship between the observed changes was examined using Spearman's correlation coefficient. In addition to testing the overall heterogeneity among the means, post hoc planned comparisons were further performed between means for the effects of cultivar (Bólyi 44, Cordoba), individual metal (control, As, Cd), and leaf position (UL-adaxial, UL-abaxial, TL-adaxial, TL-abaxial). Statistical analyses were completed with the statistical package STATISTICA 8 (StatSoft Inc. 2007).

\section{Results}

\section{Impact of Metals on Soybean Cultivars}

Root tolerance indexes (Fig. 1) identified cv. Cordoba as a relatively tolerant cultivar and cv. Bólyi 44 as relatively sensitive to both tested metals. When grown in pots, the corresponding experimental plants lacked obvious metal intoxication symptoms like wilting or chlorosis of leaves. Growth was only slightly affected by applied metal doses, while the roots (FW, DW, length) of cv. Cordoba appeared to be more affected by metals (Supplementary Fig. 1).

Metals accumulated mainly in the underground parts $(\mathrm{P}<0.05)$ (Fig. 2). Roots of the less tolerant cv. Bólyi 44 accumulated significantly more $\mathrm{Cd}^{2+}(\mathrm{P}<0.05)$ but less $\mathrm{As}^{3+}(\mathrm{P}>0.05)$ in comparison to the relatively tolerant cv. Cordoba (Fig. 2a, b). Slightly increased lignin deposition in the peripheral protoxylem and protophloem in As-exposed roots points on stress, but anatomical changes were not observed (Fig. 3). Higher amounts of As than $\mathrm{Cd}$ were transferred to shoots (in the case of cv. Bólyi 44 this was significant at $\mathrm{P}<0.05$ ) (Fig. 2c).

\section{Basic Characteristics of the Epidermal Cells in the Two Cultivars}

In control plants, the stomatal densities and SI values were lower on the adaxial side of the leaves (both cultivars, $\mathrm{P}<10^{-4}$ ) as a typical pattern for many plant species [27]. Conversely, numbers of PC were higher on the adaxial leaves sides, albeit this was significant on only the unifoliate leaf of the more tolerant cultivar $(\mathrm{P}<0.01)$. Stomata were longer on the lower leaves compared to the upper leaves in both cultivars $\left(\mathrm{P}<10^{-4}\right)$.

When comparing stomatal characteristics of the two cultivars, the SD on individual leaves (their two sides) was comparable, except for the abaxial side of
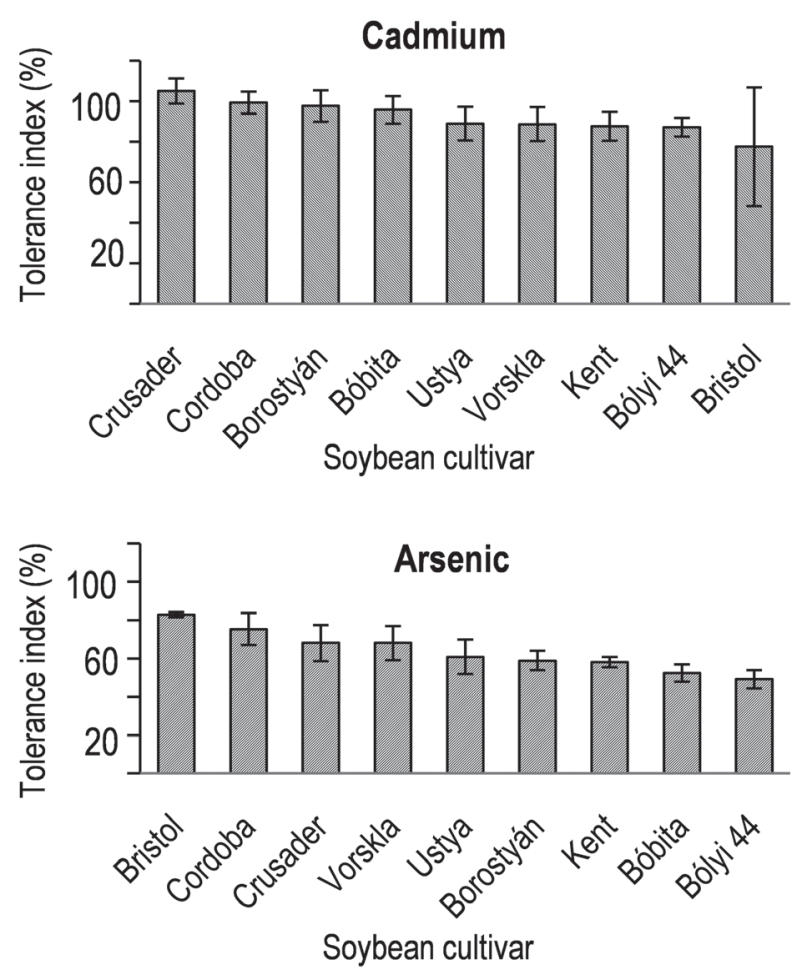

Fig. 1. Relative biomass of metal-treated roots of 9 soybean cultivars with respect to controls; tolerance index was expressed in \%; cultivars Cordoba and Bólyi 44 were selected as relatively tolerant and less tolerant cultivars for further analyses. 


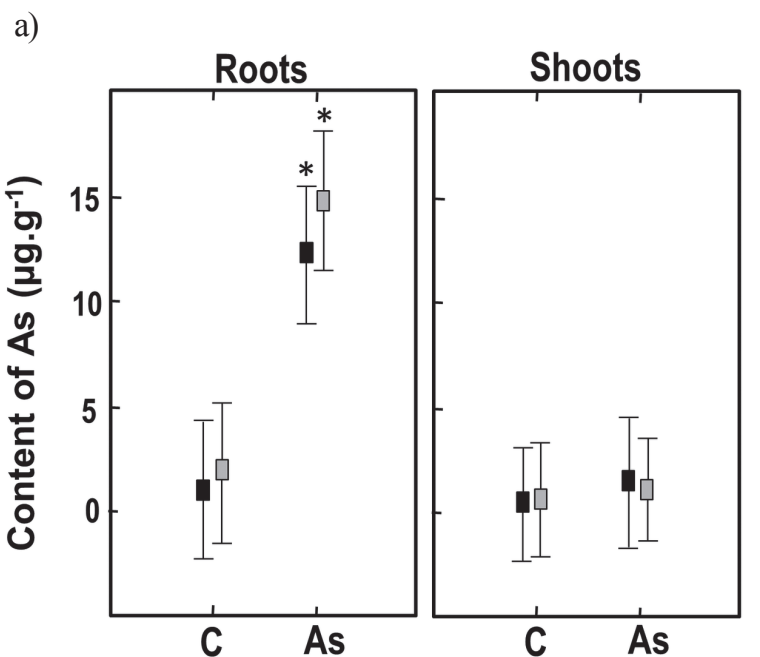

c)

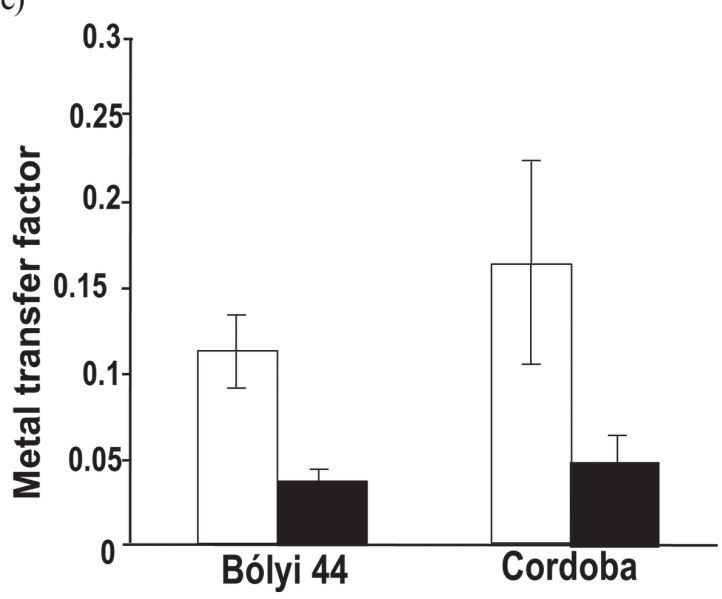

b)

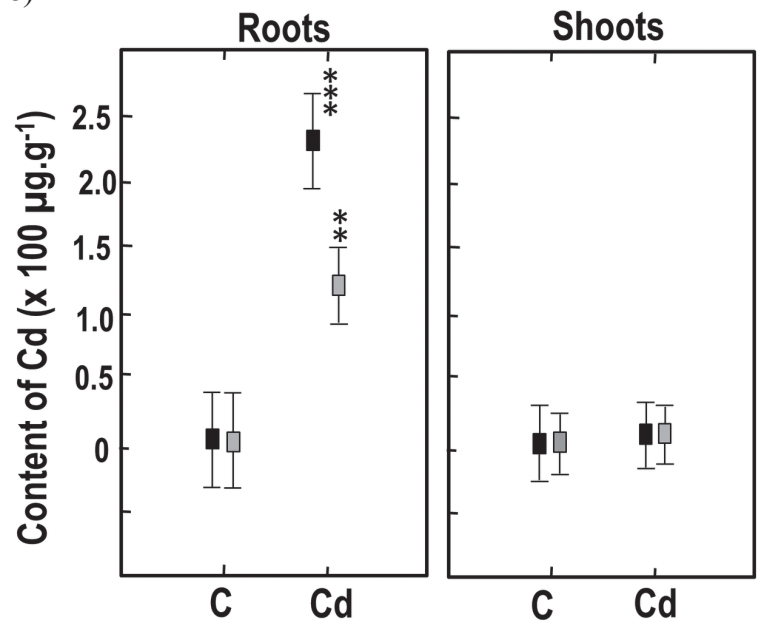

d)

\begin{tabular}{|c|c|c|c|c|c|c|}
\hline & \multicolumn{2}{|c|}{ As } & \multicolumn{2}{|c|}{$\mathrm{Cd}$} & \multicolumn{2}{|c|}{ MTf } \\
\hline & $F$ & $p$ & $F$ & $p$ & $F$ & $p$ \\
\hline$M$ & 8.80 & 0.01 & 22.20 & 0.001 & 3.22 & 0.11 \\
\hline $\mathrm{Cv}$ & 0.11 & 0.74 & 2.04 & 0.17 & 0.28 & 0.61 \\
\hline 0 & 9.80 & 0.01 & 21.03 & 0.001 & - & - \\
\hline$M \times C v$ & 0.017 & 0.90 & 2.16 & 0.16 & 0.12 & 0.73 \\
\hline$C v \times 0$ & 0.18 & 0.68 & 1.96 & 0.18 & - & - \\
\hline$M \times O$ & 6.84 & 0.05 & 19.91 & 0.001 & - & - \\
\hline$M \times O \times C v$ & 0.05 & 0.83 & 20.7 & 1.17 & - & - \\
\hline
\end{tabular}

Fig. 2. Content of metals detected in dried roots (left) and shoots (right) of two soybean cultivars after exposure to arsenic (As) (panel a), cadmium (Cd) (panel b), or water (C) for 10 days. Values for cv. Bólyi 44 are indicated with black boxes, those for cv. Cordoba with gray boxes. Metal transfer factor is indicated on panel c) with white boxes for arsenic and black boxes for cadmium. A multifactorial analysis of variance was used (panel d) to evaluate the effects of metal treatment (M), organ type (O), cultivar (Cv) and their interactions; the significance of the fixed effects $P$ are given in the corresponding table. Bars indicate \pm standard error of mean values.
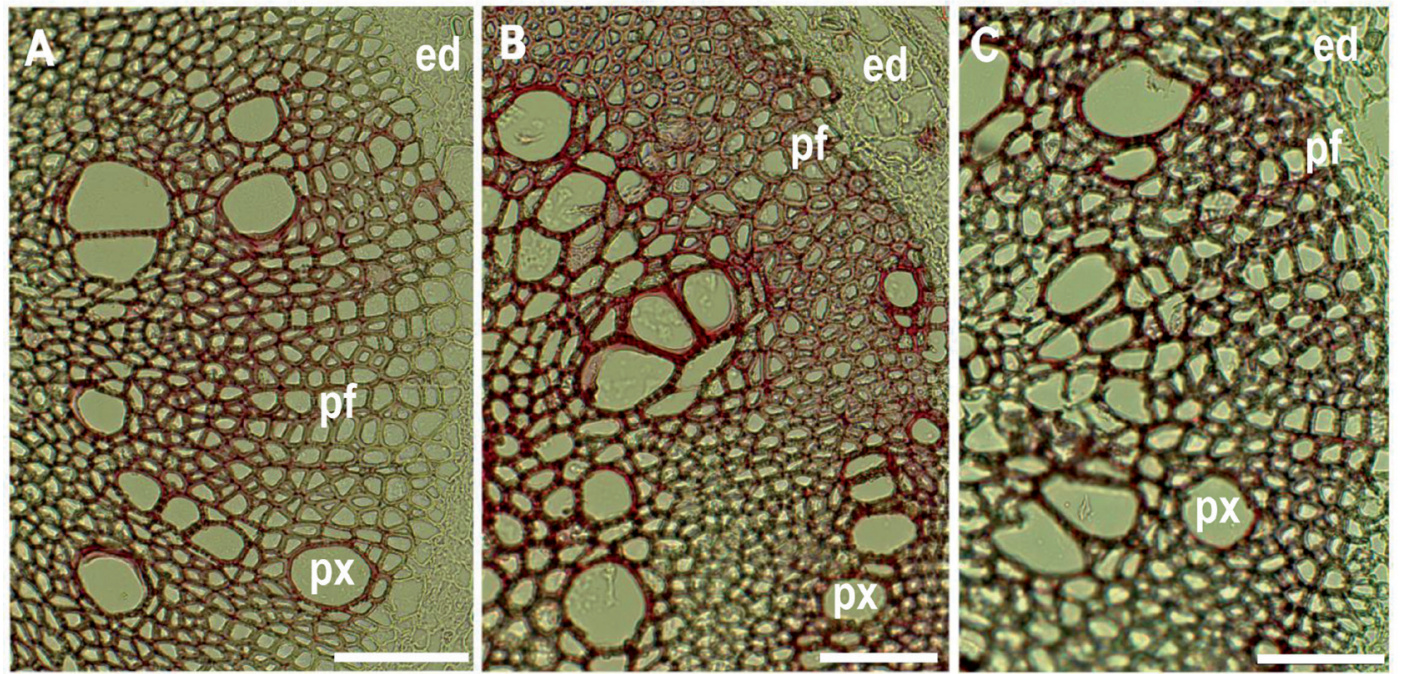

Fig. 3. Lignin deposition revealed by Wiesner reagent in cross-sections of paraffin-embedded soybean cv. Cordoba roots: (A) - watertreated plants; (B) - $\mathrm{Cd}^{2+}$-exposed plants; (C) - $\mathrm{As}^{3+}$-exposed plants; specific cell types: px - primary xylem; pf - primary phloem; ed - endodermis; scale bar $-100 \mu \mathrm{m}$. 
the trifoliate leaf (was higher in cv. Bólyi 44 at $\mathrm{P}<10^{-4}$ ) (Fig. 4a). The two cultivars did not differ in the number of pavement cells (PC), except for a higher value in variety Bólyi 44 on both sides of the trifoliate leaves (at $\mathrm{P}<0.05$ ) (Fig. 4b). Stomatal index values only differed (were higher) on the trifoliate leaf of cv. Bólyi 44 compared to the tolerant genotype $\left(\mathrm{P}<10^{-4}\right)$ (Fig. 4c). The size (area) of stomata was larger in $\mathrm{cv}$. Bólyi $(\mathrm{P}<0.001)$, except for the abaxial side of the trifoliate leaf (Fig. 4d). As to the shape, the stomata of cv. Bólyi 44 were shorter $(\mathrm{P}<0.001)$ and wider $\left(\mathrm{P}<10^{-4}\right)$ compared to the other cultivar (Fig. 4e, f). At the whole plant level the width of stomata was gradually decreasing toward the top of the plants in cv. Bólyi 44 but not of cv. Cordoba. In the latter case, wider stomata were on the abaxial leaf sides ( $\mathrm{UL}>\mathrm{TL}$ ), followed by values on abaxial sides (TL $>$ UL) (Fig. 4).

\section{Effects of As and Cd on the Leaf Epidermal Cells}

In general, the applied metal doses alone did not cause significant alterations in stomatal parameters studied (Fig. 4, Table 1). Metal-related changes in SDs were observed on the abaxial leaf surfaces (Fig. 4a). Arsenic decreased SD in the cv. Bólyi 44 (trifoliate leaf, $\mathrm{P}<0.05$ ) but not in the tolerant variety (Fig. $4 \mathrm{a}$ ). In contrast, Cd elevated SD in cv. Bólyi 44 (trifoliate leaf, $\mathrm{P}<0.01$ ), but suppressed in the other cultivar (unifoliate leaf, $\mathrm{P}<0.01$ ) (Fig. 4a). Regarding the pavement cells, only those in cv. Bólyi 44 were affected: elevated abundance was scored on the adaxial side of trifoliate $(\mathrm{P}<0.01)$ as well as unifoliate leaf $(\mathrm{P}<0.01)$ (Fig. 4b). On the other hand, Cd affected PCs in both cv. Bólyi 44 (increase on adaxial side of TL leaf) and cv. Cordoba (decrease on abaxial side of TL) (Fig. 4b). The metalcaused variations in SD and/or PC numbers were not reflected in significant alteration of the corresponding SI values (for both metal types, leaf types/sides as well as cultivars) (Fig. 4c).

Metal stress generally caused enlargement of stomatal area in the cv. Cordoba (Fig. 4d). This was significant on the adaxial side of the unifoliate leaf upon both $\mathrm{As}^{3+}$ and $\mathrm{Cd}^{2+}$ treatments, and on the abaxial side of the trifoliate leaf upon $\mathrm{Cd}^{2+}$ treatment $\left(\mathrm{P}<10^{-4}\right)$. In contrast, the stomatal area was significantly reduced in cv. Bólyi 44 on the adaxial side of unifoliate leaves stressed with both $\mathrm{As}^{3+}\left(\mathrm{P}<10^{-4}\right)$ and $\mathrm{Cd}^{2+}$ treatments $(\mathrm{P}<0.001)$. Noteworthy is the fact that the effects on stomatal area observed on the abaxial side of the TL in cv. Bólyi 44 were individually not significant. However, $\mathrm{As}^{3+}$ promoted while $\mathrm{Cd}^{2+}$ restricted leaf enlargement, and the two effects differed significantly $(\mathrm{P}<0.001)$ (Fig. 4d).

The changes of stomatal area agreed with the corresponding length and width (or both) amendments (Fig. 4e, f). In contrast, however, not all variations in stomatal features resulted in significant adaptation of stomatal area. For example, As caused an increase of stomatal width on the adaxial side of upper leaves in $\mathrm{cv}$. Bólyi, while the corresponding change of the stomatal area was not significant. Furthermore, $\mathrm{Cd}$ reduced width but increased length of stomata with no effect on stomatal area on the abaxial side of the unifoliate leaf in cv. Cordoba. This is not surprising, since SI relates to highly controlled processes such as cell division and differentiation, therefore showing much less variation to ensure a functional epidermis than SD [28].

\section{Discussion}

Doses of metal(loid), that are similar or higher than those found in polluted European areas exerted variable toxicity on the surveyed soybean cultivars similarly as described for soybean $[29,30]$ and other plant species [31] as well as lichens and mosses [32]. The cultivars Bólyi 44 and Cordoba were selected for further analyses as contrasting in metal tolerance (to both $\mathrm{As}^{3+}$ and $\mathrm{Cd}^{2+}$ ) (Fig. 1).

The two metals entailed no obvious stress symptoms on aboveground parts of stressed pot plants (e.g., wilting or chlorosis); the anatomy of the shoots, leaves and even roots remained unaffected (for shoots and leaves data not shown, for roots) (Fig. 3). Despite this,

Table 1. Overview of results of multifactorial analysis of variance; given are the values of significance $P$ for effects of fixed factors and their combinations.

\begin{tabular}{|c|c|c|c|c|c|c|c|}
\hline & $\mathrm{M}^{*}$ & $\mathrm{Cv}^{* *}$ & $\mathrm{~L} * *$ & $\mathrm{M} \times \mathrm{Cv}$ & $\mathrm{Cv} \times \mathrm{L}$ & $\mathrm{M} \times \mathrm{L}$ & $\mathrm{M} \times \mathrm{Cv} \times \mathrm{L}$ \\
\hline Stomatal density & 0.94 & $<\mathbf{0 . 0 0 1}$ & $<\mathbf{0 . 0 0 1}$ & $<\mathbf{0 . 0 5}$ & $<\mathbf{0 . 0 0 1}$ & 0.051 & 0.09 \\
\hline Stomatal width & 0.07 & $<\mathbf{0 . 0 0 1}$ & $<\mathbf{0 . 0 0 1}$ & $<\mathbf{0 . 0 0 1}$ & $<\mathbf{0 . 0 0 1}$ & 0.07 & $<\mathbf{0 . 0 0 1}$ \\
\hline Stomatal length & 0.43 & $<\mathbf{0 . 0 0 1}$ & $<\mathbf{0 . 0 0 1}$ & $<\mathbf{0 . 0 1}$ & $<\mathbf{0 . 0 0 1}$ & $<\mathbf{0 . 0 0 1}$ & $<\mathbf{0 . 0 0 1}$ \\
\hline Stomatal area & 0.56 & $<\mathbf{0 . 0 0 1}$ & $<\mathbf{0 . 0 0 1}$ & $<\mathbf{0 . 0 0 1}$ & $<\mathbf{0 . 0 0 1}$ & 0.18 & $<\mathbf{0 . 0 0 1}$ \\
\hline Stomatal index & 0.76 & $<\mathbf{0 . 0 0 1}$ & $<\mathbf{0 . 0 0 1}$ & 0.77 & 0.08 & $<\mathbf{0 . 0 0 1}$ & 0.66 \\
\hline Number of Pavement cells & 0.10 & $<\mathbf{0 . 0 0 1}$ & $\mathbf{< 0 . 0 0 1}$ & $<\mathbf{0 . 0 2}$ & $<\mathbf{0 . 0 0 1}$ & 0.19 & $<\mathbf{0 . 0 0 1}$ \\
\hline
\end{tabular}

* metal treatment (control, arsenic and cadmium) (throughout the table)

** cultivar (Bólyi 44 and Cordoba) (throughout the table)

*** leaf type/side (unifoliate-abaxial, unifoliate-adaxial, trifoliate-abaxial, trifoliate-adaxial) (throughout the table) 

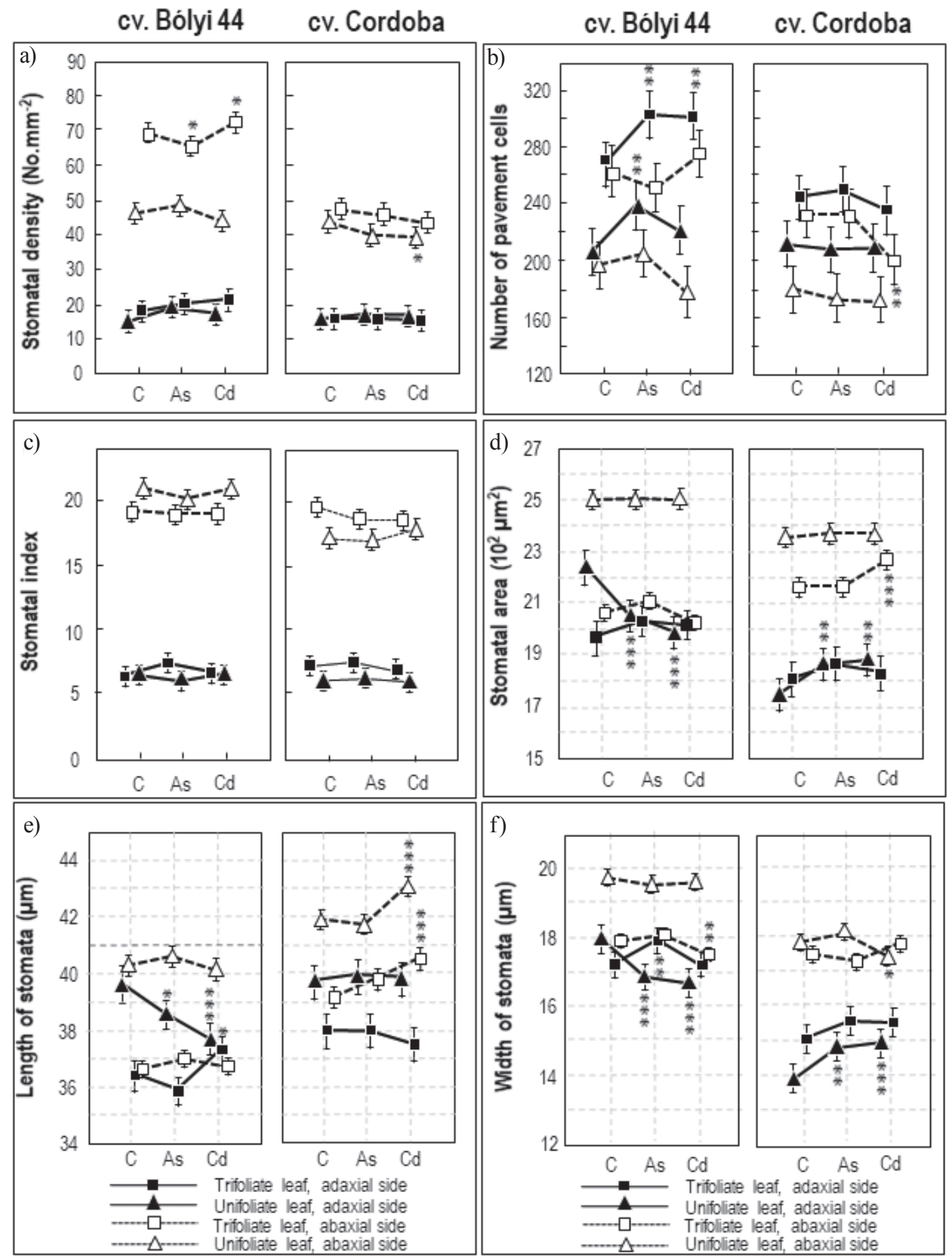

Fig. 4. Parameters of leaf epidermal cells after exposure of plants of two soybean cultivars to arsenic (As), cadmium (Cd) or water (C) for 10 days. We examined the unifoliate (triangles) and trifoliate (squares) leaves on adaxial- (filled labels) as well as abaxial sides (empty labels). Bars indicate \pm standard error of mean values. To enhance the transparency of data, values for the two cultivars are shown separately. Furthermore, data on the adaxial leaf side are connected with full lines and those on abaxial side with dashed lines (referring to similar type of leaves, respectively). Significant effects of the metal treatment are indicated with asterisk * at $\mathrm{P}<0.05, * * \mathrm{P}<0.01$, $* * * \mathrm{P}<0.001$, directly above- or below the corresponding label (bar). An overview of the results of multifactorial ANOVA analysis is given in Table 1.

growth was impaired, more markedly of sensitive cv. Bólyi 44. Previously, similar doses have evoked mild but significant responses in soybean plants [29, 33]. In contrast, irregularly lignified conducting elements have been observed in vascular tissue of pea seedlings exposed to lead and arsenate [34]. Both soybean cultivars prevented metal(oid)s to amass in the aboveground plant parts as reported by others [31]. Since soot-to-shoot metal translocation depends on the transpiration flow [13] regulated by stomata and their parameters/activity, 
natural differences between the leaf epidermal cells might contribute to the metal allocation pattern. For studied cultivars, the stomata in the cv. Bólyi were in general larger (shorter and wider) $(\mathrm{P}<0.001)$ compared to $\mathrm{cv}$. Cordoba $(\mathrm{P}<0.001)$, at both abaxial- and adaxial leaf sides (respectively). Nevertheless, the two cultivars have exerted no differences in chlorophyll fluorescence at shoot level [29].

Natural selection under diverse conditions might have resulted in natural variants that ensure higher use of carbon resources [20] and/or incorporate adaptive responses of stomata to environmental cues [19, 21]. The response of leaf epidermis is metal-specific and non-concentration dependent [19], but opposing observations were reported as well [13]. Adaxial culticular features are key in assisting high metal absorption from air via adaxial surfaces [6], while abaxial parameters are more affected under growth in metal-polluted soil. The observed effects of As and $\mathrm{Cd}$ on stomata suggests higher metal-sensitivity of the abaxial stomata (especially in less tolerant cv. Bólyi 44), in agreement with previous studies with sunflower and several other plant species [35 and herein]. The plants of cv. Bólyi 44 adjust several stomatal features to cope with As toxicity in contrast to cv. Cordoba, for which enlargement of stomata was the only change detected (Fig. 5). The many more stomatal responses observed upon treatment with $\mathrm{Cd}$ mostly coincide with those induced by As. Importantly, the two cultivars appear to differently adjust stomatal densities. The less tolerant cultivar responds with increased number of stomata under metal stress described also by others [36, 37], probably due to the reduction of guard cell size under water deficit, rather than due to enhanced stomata formation [12]. According to Melo et al. [38], increased $\mathrm{SD}$ is coupled with decreased stomatal size (pores) that controls the supply of $\mathrm{CO}_{2}$ for photosynthesis with concurrent prevention of excessive water loss, and could be a compensatory measure to the reduced transpiration area [39]. In contrast, we observed a decline of SD in cv. Cordoba. Similar observation has been reported when the whole leaf was counted (not the

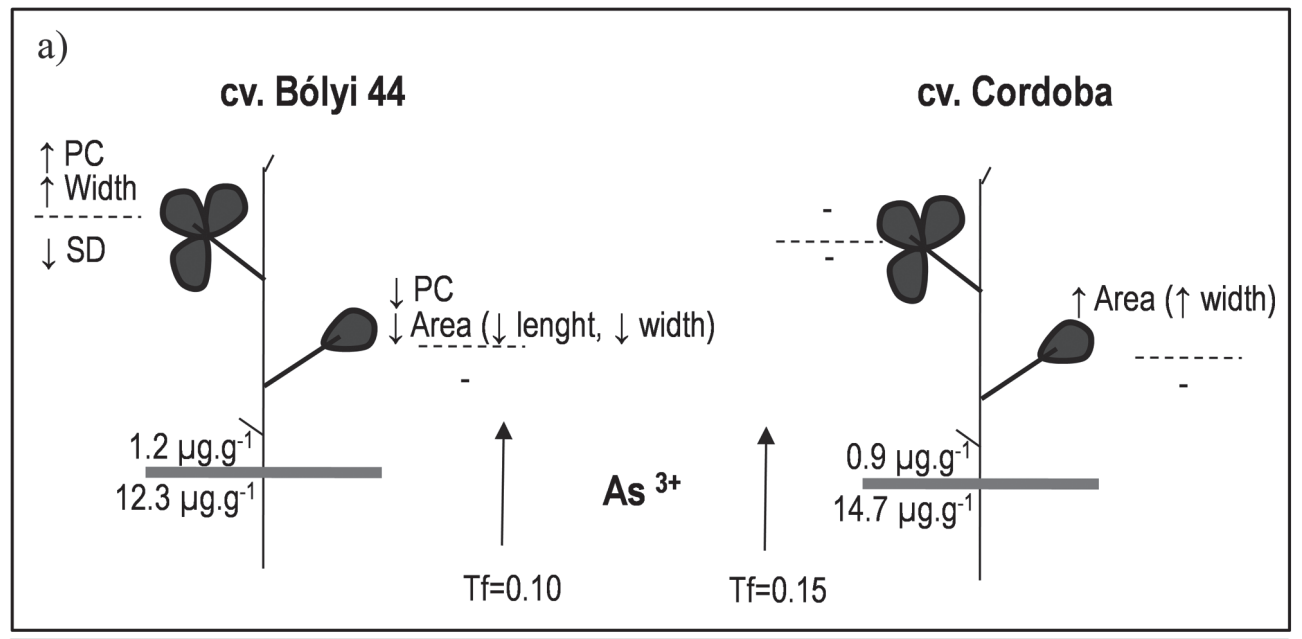

b)

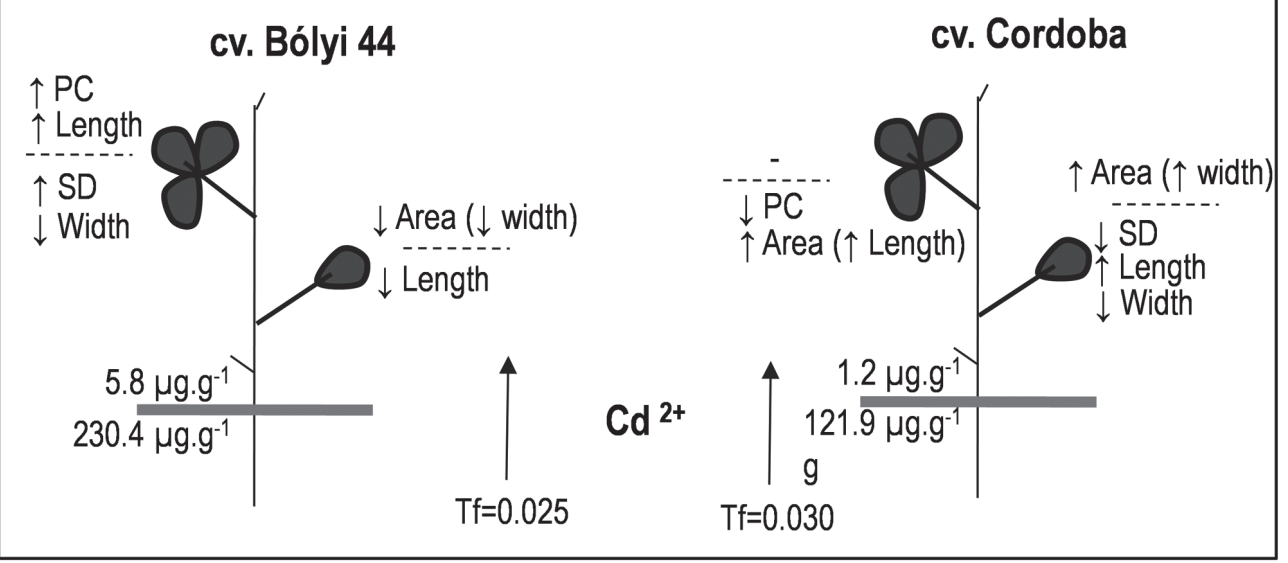

Fig. 5. Overview of the significant adjustments of densities of stomata (SD) and pavement cells (PC), and alterations in length, width and area of stomata. We examined the unifoliate and trifoliate leaves of plants of two soybean cultivars upon exposure to arsenic (As) (panel a) and cadmium (Cd) (panel b). The dashed lines next to each individual leaf separate the adjustments on the adaxial (upper) and abaxial (lower) leaf sides. Increases or decreases of a parameter are indicated by the direction of the arrow. Given are the amounts of metals detected in the shoots (aboveground) and roots (given for dry weight), as well as the values of metal transfer factor (Tf). 
internal leaf part as in our case) [36], upon sorghum treatment with $\mathrm{Cu}$ and $\mathrm{Cd}$ [40], bean exposure to $\mathrm{Zn}$ [41], in red maple under combined drought and metal stress [42] and in drought-stressed barley [43]. Peel et al. [44] reported that stomatal density inversely relates to leaf size changes under stress, but this do not seem to be our case. Decline of stomatal frequency might occur on account of metal toxicity and can result in abnormal shape (and function) stomata [12 and within]; however, we did not observe this phenomenon in our experiment. Noteworthy is the fact that fewer stomata in $\mathrm{Cd}^{2+}$-stressed cv. Cordoba plants were longer and larger (opposing to cv. Bólyi 44). Abrams et al. [45] correlated the stomatal cell length with stomatal conductance, while smaller stomata are considered to show faster dynamic characteristics, greater (long-term) water use efficiency and higher photosynthetic capacity [46-48 and herein]. The compensatory relationship of stomatal features aims to keep the total pore area best under given conditions in an integrated and hierarchical manner [20].

The responses of stomata were not uniform throughout the plant as opposing adjustments were observed on two different leaf types, pointing to a spatial variation in leaf epidermal (stomatal) responses under dehydration [20] as well as metal stress (e.g., on the number of PCs and stomatal width) (Figs 4, 5). Previously, a close relationship has been shown between the age and type of the leaf tissue and response of the photosynthetic apparatus to $\mathrm{Cd}$ [23], possibly through different accumulation of compounds involved in metal chelatation and detoxification [22]. Remarkably, we also observed dorsoventral response in stomatal parameters (width) on the unifoliate leaf of cv. Cordoba in response to $\mathrm{Cd}$. The amfistomatous nature of soybean leaves enables moving the stomata on both sides independently, while their diverse regulation possibly results from the otherness in the structures of palisade tissue and spongy tissue, the photosynthetic translocation and/ or the signal transduction pathways on the two leaf sides [35]. To our knowledge, leaf-side-specific stress effects have yet been observed upon dark [49], dark chilling [50], elevated $\mathrm{CO}_{2}, \mathrm{ABA}$ treatment $[51,52]$ or water deficit [53]. However, it remains to be elucidated if metal(oid) exposure also results in any functional polarity of stomata on the two leaf sides, as it has been observed with regard to the $\mathrm{CO}_{2}$ enrichment in maize [54]. Nevertheless, responses that can differ in various plant areas might be advantageous in enabling a more efficient (local) response without losing unnecessary amounts of water, as well as in opportunistic capture of resources [20, 55].

In conclusion, plants of the two selected soybean cultivars accumulated significant amounts of metals in root tissues. Despite low impact on growth, we detected diverse adjustments of epidermal cells as components of different defense strategies against metals in the two cultivars. In more sensitive cv. Bólyi 44, stomatal area decreased likely to prevent further water loss and dehydration. In contrast, in cv. Cordoba stomatal enlargement was observed possibly to alter conductance and adjust water use efficiency. Abnormal stomata were absent in studied tissue, but dorsoventral width adjustments were scored in cv. Cordoba. To our knowledge, dorsoventral stomatal responses have not been reported yet in the context of metal toxicity, while representing probably a rather peculiar local response of leaves to water shortage, direct metal toxicity or both. Features and flexibility of stomatal responses to metals is important for plant survival since changes of stomatal pore sizes relate to hydraulic dysfunction [56]. Our results confirm that they are apparently rather variable even within a species, thus representing a potential screening tool to identify genotypes tolerant to metals, drought and other stress types. Furthermore, they point to the importance of considering changes at the whole plant level, since the energetic demands on individual tissues are likely different and therefore the tradeoff between development and defence (success) plays a significant role. Because of the natural variability in not only aperture (dynamics) but also cell features of leaf epidermis (stomata), the nature and efficiencies of responses to (metal) stress are probably highly complex and are relevant not only for metal uptake by roots but even more by stomata $[6,57]$.

\section{Acknowledgements}

This work was supported by grants from the Slovak Grant Agency VEGA No. VEGA 1-0048-19 and by the Slovak Research and Development Agency under contract number APVV-15-0051.

\section{Conflict of Interest}

The authors declare no conflict of interest. 
cv. Bólyi 44
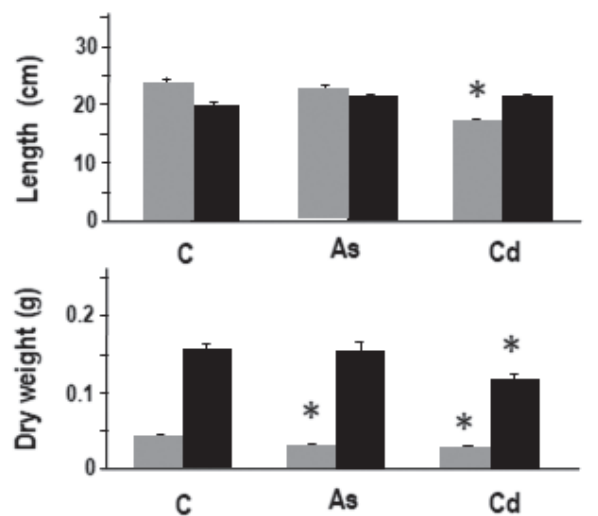

$\mathrm{Cd}$

\begin{tabular}{lccc}
\hline & $\boldsymbol{M}$ & $\boldsymbol{C V}$ & $\boldsymbol{M} \boldsymbol{x} \mathbf{C v}$ \\
\hline Root lenght & 0.24 & 0.77 & $\mathbf{0 . 0 2}$ \\
Root DW & 0.47 & 0.97 & 0.19 \\
Shoot length & 0.41 & $\mathbf{0 . 0 0 1}$ & 0.49 \\
Shoot DW & 0.49 & 0.08 & 0.09 \\
\hline
\end{tabular}

cv. Cordoba

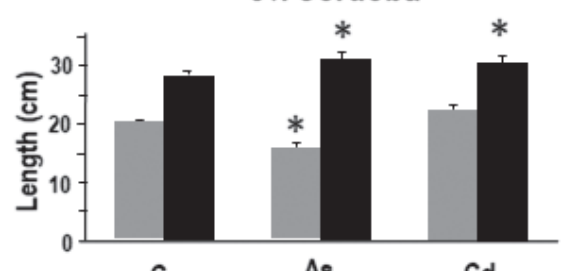

As Cd

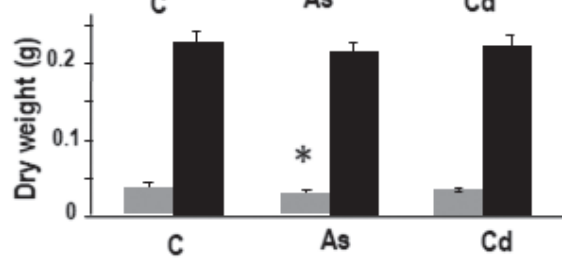

Supplementary Fig. 1. Selected growth parameters of soybean roots (gray columns) and shoots (black columns) after exposure to given doses of arsenic (As), cadmium (Cd) or water (C) for 10 days. Bars indicate \pm standard error of mean values. Significant effect of metal treatment with respect to controls is indicated with an asterisk $(\mathrm{P}<0.05)$. Rightwards, photographs of experimental plants are shown. A multifactorial analysis of variance was used to evaluate the effects of metal treatment (M), cultivar (Cv) and their interactions; the significance of effects $P$ are given in the corresponding table.

\section{References}

1. EDELSTEIN M., BEN-HUR M. Heavy metals and metalloids: Sources, risks and strategies to reduce their accumulation in horticultural crops. Sci. Hortic. Amsterdam 234, 431, 2018.

2. ALAM M.Z., HOQUE M.A., AHAMMED G.J., MCGEE R., CARPENTER-BOGGS L. Arsenic accumulation in lentil (Lens culinaris) genotypes and risk associated with the consumption of grains. Sci. Rep. 9, (1), 2019.

3. DRAGUN A.K. The agricultural production of environment - some Nordic issues. Swed. J. Agric. Res 28, 49, 1998.

4. HRONEC O. Fumes - soil - vegetation. Prešov: TOP, 1996.

5. PAN J., PLANT J.A., VOULVOULIS N., OATES C.J., IHLENFELD C. Cadmium levels in Europe: implications for human health, Environ. Geochem. Health. 32, (1), 1, 2010.

6. SHAHID M., DUMAT C., KHALID S., SCHRECK E., XIONG T., NIAZI N.K. Foliar heavy metal uptake, toxicity and detoxification in plants: A comparison of foliar and root metal uptake. J. Haz. Mat. 325, 36, 2017.

7. HUYBRECHTS M., CUYPERS A., DECKERS J., IVEN V., VANDIONANT S., JOZEFCZAK M., HENDRIX S. Cadmium and plant development: An agony from seed to seed. Int. J. Mol. Sci. 20 (16), 3971, 2019.

8. ABBAS G., MURTAZA B., BIBI I., SHAHID M., NIAZI N.K., KHAN M.I., AMJAD M., HUSSAIN M., NATASH A. Arsenic uptake, toxicity, detoxification, and speciation in plants: Physiological, biochemical, and molecular aspects. Int. J. Environ. Res. Public Health 15 (1), 59, 2018.

9. MURUGAIYAN V., ALI J., MAHENDER A., ASLAM U.M., JEWEL Z.A., PANG Y., MARFORI-NAZAREA C.M., WU L.-B., FREI M., LI Z. Mapping of genomic regions associated with arsenic toxicity stress in a backcross breeding populations of rice (Oryza sativa L.), Rice 12 (1), 61, 2019.

10. DEMECSOVÁ L., TAMÁS L. Reactive oxygen species, auxin and nitric oxide in metal-stressed roots: toxicity or defence. BioMetals 32 (5), 717, 2019.

11. KAPOOR D., SINGH M.P., KAUR S., BHARDWAJ R., ZHENG B., SHARMA A. Modulation of the functional components of growth, photosynthesis, and anti-oxidant stress markers in cadmium exposed Brassica juncea L. Plants 8 (8), 260, 2019.

12. RUCIŃSKA-SOBKOWIAK R. Water relations in plants subjected to heavy metal stresses. Acta Physiol. Plant. 38, (11), 2016.

13. PERFUS-BARBEOCH L., LEONHARDT N., VAVASSEUR A., FORESTIER C. Heavy metal toxicity: cadmium permeates through calcium channels and disturbs the plant water status. Plant J. 32 (4), 539, 2002.

14. MISRA B.B., REICHMAN S.M., CHEN S. The guard cell ionome: Understanding the role of ions in guard cell functions. Progr. Biophys. Mol. Bio. 146, 50, 2019.

15. O'LEXY R., KASAI K., CLARK N., FUJIWARA T., SOZZANI R., GALLAGHER K.L. Exposure to heavy metal stress triggers changes in plasmodesmatal permeability via deposition and breakdown of callose. J. Exp. Bot. 69 (15), 3715, 2018

16. MIZUTANI M., KANAOKA M.M. Environmental sensing and morphological plasticity in plants. Semin. Cell Dev. Biol. 83, 69, 2018.

17. ROCKWELL F.E., HOLBROOK N.M. Leaf hydraulic architecture and stomatal conductance: A functional perspective. Plant Physiol. 174 (4), 1996, 2017.

18. SUBBA P., MUKHOPADHYAY M., MAHATO S.K., BHUTIA K.D., MONDAL T.K., GHOSH S.K. Zinc stress induces physiological, ultra-structural and biochemical changes in mandarin orange (Citrus reticulata Blanco). 
Physiol. Mol. Biol. Plants 20 (4), 461, 2014.

19. JAIME R., SERICHOL C., ALCÁNTARA J.M., REY P.J. Differences in gas exchange contribute to habitat differentiation in Iberian columbines from contrasting light and water environments. Plant Biol. 16 (2), 354, 2014.

20. 20. MCAUSLAND L., VIALET-CHABRAND S., MATTHEWS J., LAWSON T. Spatial and temporal responses in stomatal behaviour, photosynthesis and implications for water-use efficiency. In. MANCUSO S., SHABALA S. eds., Rhythms in Plants: Dynamic Responses in a Dynamic Environment. Springer, Cham, 2015.

21. QI X., TORII K.U. Hormonal and environmental signals guiding stomatal development. BMC Biol. 16 (1), 21, 2018.

22. KUTROWSKA A., SZELAG M. Low-molecular weight organic acids and peptides involved in the long-distance transport of trace metals. Acta Physiol. Plant. 36 (8), 1957, 2014.

23. DOBROVICZKÁ T., PIRŠELOVÁ B., MÉSZÁROS P., BLEHOVÁ A., LIBANTOVÁ J., MORAVČÍKOVÁ J., MATUŠÍKOVÁ I. Effects of cadmium and arsenic ions on content of photosynthetic pigments in the leaves of Glycine $\max ($ L.) Merrill. Pak.J. Bot. 45, (1), 105, 2013.

24. BOARD J.E., KAHLON C.S. Soybean yield formation: what controls it and how it can be improved. In: El-Shemy HA, ed. Soybean physiology and biochemistry. Rijeka: InTech, 1. 2011.

25. ElOBEID M., GOEBEL C., FEUSSNER I., POLlE A. Cadmium interferes with auxin physiology and lignification in poplar. J. Exp. Bot. 63 (3), 1413, 2012.

26. WENG J.-K., AKIYAMA T., BONAWITZ N.D., LI X., RALPH J., CHAPPLE C. Convergent evolution of syringyl lignin biosynthesis via distinct pathways in the lycophyte Selaginella and flowering plants. Plant Cell 22, 1033, 2010.

27. MARTIN C., GLOVER B.J. Functional aspects of cell patterning in aerial epidermis. Curr. Opin. Plant Biol. 10, (1), 70, 2007.

28. DELGADO D., ALONSO-BLANCO C., FENOLL C., MENA M. Natural variation in stomatal abundance of Arabidopsis thaliana includes cryptic diversity for different developmental processes. Ann. Bot. 107, (8), 1247, 2011.

29. PIRŠELOVÁ B., BOLEČEK P., GÁLUSOVÁ T. Effect of cadmium and arsenic on chlorophyll fluorescence of selected soybean cultivars. Russ. J. Plant Physiol. 63, (4), 469, 2016.

30. GÁLUSOVÁ T., RYBANSKÝ L., MÉSZÁROS P., SPIEß N., PIRŠELOVÁ B., KUNA R., LIBANTOVÁ J., MORAVČÍKOVÁ J., HAUPTVOGEL P., MATUÍKOVÁ I. Variable responses of soybean chitinases to arsenic and cadmium stress at the whole plant level. Plant Growth Regul. 76, (2), 147, 2015.

31. RONZAN M., PIACENTINI D., FATTORINI L., DELLA ROVERE F., EICHE E., RIEMANN M., ALTAMURA M.M., FALASCA G. Cadmium and arsenic affect root development in Oryza sativa L. negatively interacting with auxin. Env. Exp. Bot. 151, 64, 2018.

32. WRIGHT L.P., ZHANG L., CHENG I., AHERNE J., WENTWORTH G.R. Impacts and effects indicators of atmospheric deposition of major pollutants to various ecosystems-A review. Aerosol Air Qual. Res. 18 (8), 1953, 2018.

33. PERALTA J.R., GARDEA-TORRESDEY J.L., TIEMANN K.J., GOMEZ E., ARTEAGA S., RASCON E., PARSONS J.G. Uptake and effects of five heavy metals on seed germination and plant growth in alfalfa (Medicago sativa L.). Bull. Environ. Contam. Toxicol. 66 (6), 727, 2001.

34. PÄIVÖKE A.E.A., SIMOLA L.K. Arsenate toxicity to Pisum sativum: Mineral nutrients, chlorophyll content, and phytase activity. Ecotoxicol. Environ. Safe. 49, (2), 111, 2001.

35. WANG Y., NOGUCHI K., TERASHIMA I. Distinct light responses of the adaxial and abaxial stomata in intact leaves of Helianthus annuus L. Plant Cell Environ. 31 (9), 1307, 2008.

36. WERYSZKO-CHMIELEWSKA E., CHWIL M. Leadinduced histological and ultrastructural changes in the leaves of soybean (Glycine max (L.) Merr.). Soil Sci. Plant Nutr. 51 (2), 203, 2005.

37. FARBER M., ATTIA Z., WEISS D. Cytokinin activity increases stomatal density and transpiration rate in tomato. J. Exp. Bot. 67, 6351, 2016.

38. MELO H.C., CASTRO E.M., SOARES A.M., MELO L.A., ALVES J.D. Anatomical and physiological alterations in Setaria anceps Stapf ex Massey and Paspalum paniculatum L. under water deficit conditions. Hoehnea 34, 145, 2007.

39. SCHULER M.L., SEDELNIKOVA O.V., WALKER B.J., WESTHOFF P., LANGDALEA J.A. SHORTROOTmediated increase in stomatal density has no impact on photosynthetic efficiency. Plant Physiol. 176 (1), 757, 2018.

40. KASIM W.A. Changes induced by copper and cadmium stress in the anatomy and grain yield of Sorghum bicolor Moench. Int. J. Agric. Biol. 81, 23, 2006.

41. SAGARDOY R., VÁZQUEZ S., FLOREZ-SARASA I.D., ALBACETE A., RIBAS-CARBÓ M., FLEXAS J., ABADÍA J., MORALES F. Stomatal and mesophyll conductances to $\mathrm{CO}_{2}$ are the main limitations to photosynthesis in sugar beet (Beta vulgaris) plants grown with excess zinc. New Phytol. 187, (1), 145, 2010.

42. DE SILVA N.D.G., CHOLEWA E., RYSER P. Effects of combined drought and heavy metal stresses on xylem structure and hydraulic conductivity in red maple (Acer rubrum L.). J. Exp. Bot. 63, 5957, 2012.

43. HUGHES J., HEPWORTH C., DUTTON C., DUNN J.A., HUNT L., STEPHENS J. Reducing stomatal density in barley improves drought tolerance without impacting on yield. Plant Physiol. 174, 776, 2012.

44. PEEL JOANNE R., MANDUJANO SÁNCHEZ, MARÍA C., LÓPEZ PORTILLO JORGE, GOLUBOV JORDAN Stomatal density, leaf area and plant size variation of Rhizophora mangle (Malpighiales: Rhizophoraceae) along a salinity gradient in the Mexican Caribbean. Rev. Biol. Trop. 65 (2), 701, 2017.

45. ABRAMS M.D., KUBISKE M.E., MOSTOLLER S.A. Relating wet and dry year ecophysiology to leaf structure in contrasting temperature tree species. Ecology 75, 123, 1994.

46. RASHIDI F., JALILI A., KAFAKI S.B., SAGHEBTALEBI K., HODGSON J. Anatomical responses of leaves of Black Locust (Robinia pseudoacacia L.) to urban pollutant gases and climatic factors. Trees-Struct. Funct. 26 (2), 363, 2012.

47. DRAKE P.L., FROEND R.H., FRANKS P.J. Smaller, faster stomata: Scaling of stomatal size, rate of response, and stomatal conductance. J. Exp. Bot. 64 (2), 495, 2013.

48. KAZNINA N.M., TITOV A.F., BATOVA Y.V., LAIDINEN G.F. The resistance of plants Setaria veridis (L.) Beauv. to the influence of cadmium. Biol. Bull. 41, (5), 428, 2014. 
49. BALCEROWICZ M., RANJAN A., RUPPRECHT L., FIENE G., HOECKER U. Auxin represses stomatal development in dark-grown seedlings via Aux/IAA proteins. Development 141, 3165, 2014.

50. SOARES-CORDEIRO A.S., DRISCOLL S.P., ARRABACA M.C., FOYER C.H. Dorsoventral variations in dark chilling effects on photosynthesis and stomatal function in Paspalum dilatatum leaves. J. Exp. Bot. 62 (2), 687, 2011.

51. HUANG B., WANG Y., HUANG S., MA S. Guard cells on adaxial and abaxial epidermes of Erythrina corallodendron sepals. Biol. Plantarum 55 (4), 716, 2011.

52. LE J., LIU X.G., YANG K.Z., CHEN X.L., ZOU J.J., WANG H.Z. Auxin transport and activity regulate stomatal patterning and development. Nat. Commun. 5, 3090, 2014.

53. WANG M.H., WANG J.R., ZHANG X.W., ZHANG A.P., SUN S., ZHAO C.M. Phenotypic plasticity of stomatal and photosynthetic features of four Picea species in two contrasting common gardens. AoB Plants 11 (4), 34, 2019.

54. DRISCOLL S.P., PRINS A., OLMOS E., LAWLOR D.W., KUNERT K.J., FOYER C.H. Acclimation of adaxial and abaxial stomatal structure and function to increased $\mathrm{CO}_{2}$ availability in maize leaves. S. Afr. J. Bot. 72 (2), 319, 2006.

55. WANG X., YAN H., LI Y. Diffuse light weakens the dorsoventral asymmetry of photosynthesis in sorghum leaves. PeerJ 6, 27267, 2018.

56. AASAMAA K., SOBER A., RAHI M. Leaf anatomical characteristics associated with shoot hydraulic conductance, stomatal conductance and stomatal sensitivity to changes of leaf water status in temperate deciduous trees. Aust. J. Plant Physiol. 28 (8), 765, 2001.

57. ALLAHNOURI M., GHASEMI AGHBASH F., PAZHOUHAN I. Traffic effects on leaf macroand micromorphological traits. Folia Oecol. 45, 92, 2018. 